\title{
Renewables finance and investment: how to improve industry with private capital in China
}

\author{
Pingkuo LIU ${ }^{1}$, Penghao CHU $^{1}$
}

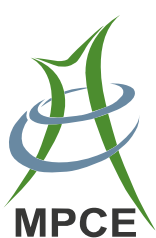

\begin{abstract}
One purpose of stimulating financing and investment through private capital is to absorb a higher proportion of renewables and promote renewable industry development. This paper first reviews the current overall situation of renewables financing and investment, and further analyzes the policy environment with respect to the development plan, regulation and special funds. Based on the analysis of the status quo, the paper then discusses the internalities and the externalities that have driven the changes of private capital investment in renewable energy projects, illustrated by a strengths weaknesses opportunities threats (SWOT) analysis. An ideal financing model, public-private partnership and distributed energy resources pattern are analyzed to identify key arrangements and design proper development schemes for both private investors and the government. If China can overcome the defects and obstacles in a reasonable and orderly fashion, the financing and investment problem of China's renewables industry will be solved in many ways. Private capital in the Chinese renewable energy market will bring great incentive if the entire industry can select some promising sub-industries in the renewables sector and choose some appropriate operation modes.
\end{abstract}

CrossCheck date: 19 July 2018

Received: 1 December 2017/Accepted: 19 July 2018/Published online: 29 December 2018

(c) The Author(s) 2018

$\triangle$ Pingkuo LIU

pingoforever@sina.com

Penghao CHU

www.cphde@qq.com

1 College of Economics and Management, Shanghai University of Electric Power, Shanghai 200090, China
Keywords Renewable industry, Ideal financing model, Public-private partnership, Distributed energy resources

\section{Introduction}

During the " $12^{\text {th }}$ Five-Year" period (2010-2015), China's renewable energy industry has turned a new page in which renewables develop in a comprehensive way towards mass production, extensive incremental substitution and regional stock substitution [1-3]. On the one hand, the role of renewables in promoting energy structure adjustment continues to increase [1-3]. On the other hand, the level of China's renewable energy technology and equipment has been significantly improved [1-3]. Various technologies for developing renewables, such as in biomass energy, geothermal energy, marine energy and renewable energy storage, have also made great progress. According to the Sputnik News Agency on May $17^{\text {th }}, 2017$, the latest edition of the Renewable Energy Country Attractiveness Index (RECAI) of Ernst \& Young (EY) sees China becoming the most attractive market in the field of renewable energy investment [4]. China jumped to first place because of its green energy policies which include the fact that China will plow $\$ 361$ billion into renewable power generation by 2020 [5, 6]. However, there is an approximately $\$ 9$ billion funding gap for China's renewable energy industry to overcome [7].

Renewables in developing countries move steadily, year after year, deeper into the mainstream investment agenda. This trend has been supported by substantial progress in the design and innovation of finance policy [8]. Nelson et al. pointed out that renewables' financing in emerging economies faces particularly daunting challenges, but there are creative policy solutions that could potentially reduce 
the cost of renewables [9]. The current relevant research publications on renewables' financing \& investment focus on three aspects, viz. quantitative analysis by modeling, investment policy suggestions, and the investment \& financing mode. Jørgensen et al. combined two different approaches (renewable resource harvesting with capital investments, and investment policy under a borrowing/ lending constraint) to study a dynamic optimization problem in capital investment and financing [10]. By using a microeconomic model and taking all stakeholders including the government, banks and shareholders of the firm into consideration, Nie et al. found that financial debts stimulate firms' outputs but decrease the net profit per unit of debt because of limited liability effects [11]. He et al. used a variable intercept model with fixed effects to measure how environmental uncertainty influences renewables' investment through external financing and used regression discontinuity to estimate the effect of renewable energy policy [12]. By analyzing five financing modes for the renewable industry in China, Chang found that the government's support is not sufficient, the market financing channel is not unblocked, underinvestment of entities is crucial, and financial institutions lack investment enthusiasm [13]. Most importantly, some scholars have noted the investment \& financing mode [14]. Manos et al. reviewed the methodology of implementing public-private-partnerships in Southern Europe, and proposed a comprehensive methodology to apply a public-private partnership (PPP) scheme [15]. Emmanuel Cedrick et al. reviewed the externalities that have driven the increase of renewables projects, and analyzed the successful international PPP practices in the renewable energy sector to identify key arrangements that contribute towards mitigating the risks attached to a particular renewable energy project [16]. Zhang Tian et al. analyzed the application status and adaptability of the PPP model in China's small hydropower industry, and offered a proposal to improve the PPP legal system, implement demonstration pilot projects, and enrich the type of PPP modes [17].

\section{Status quo}

\subsection{Finance and investment situation}

China's renewables industry, especially the renewable energy power generation industry, has shown a growth trend year on year (as shown in Table 1 and Fig. 1). The hydropower development of China started earliest [18], while the wind power industry has also been developing rapidly [19]. The biomass power generation industry is still in its initial stage [20], as is photovoltaic power generation [21, 22] (as shown in Fig. 2). If China continues to promote energy supply diversification, renewables will probably provide more than $30 \%$ of China's energy demand by 2050 [5].

In 2015, the total renewables investment of China reached $\$ 103$ billion, accounting for $36.1 \%$ of the world's total. In 2016, however, China's investment fell to $\$ 78$ billion, and thus the upward trend of the investment over the past 11 years has been broken [23]. There is also a similar trend in the Chinese government's investment for the renewable energy power generation industry, as shown in Table 2. The growth of investment in power generation projects has been so slow since 2010, relying mainly on the investment in the Chinese renewables sector [24].

Bank credit plays an important role in wind power investment, while government funds and venture capital are the main driving forces for the development of biomass and photovoltaic power generation in China [25]. The sources of funds for China's renewables finance \& investment can be listed in two categories: 1) According to the nature of funds, the investment consists of a financial fund, a social fund and a foreign fund; 2) With respect to the financing channels, the investment is composed of central finance, local finance, bank, stock market, bond, venture capital, private placements, enterprise self-raised fund and public fund. Table 3 shows the changes in the structure of renewables financing \& investment in China, which shows that bank investment still occupies a large proportion in China's renewables industry investment structure, but the share of private capital investment increases year on year (from $14.1 \%$ to $30.2 \%$ ).

According to the "IEA Medium-Term Renewable Energy Market Report 2016", Chinese enterprises have set a new record in the field of renewables development. The prediction the International Energy Agency (IEA) made is illustrated in Fig. 3. This suggests that China alone will be responsible for $37 \%$ of global renewable power growth in 2021. In fact, in 2015, the investment in China's renewables industry accounted for $1 / 3$ of the world's total [26]. Soon afterwards China made a record $\$ 32$ billion in overseas investment deals for the acquisition of overseas renewable energy and transmission assets in 2016 alone, marking a 60 percent year-on-year rise in spending [27].

In the " $13^{\text {th }}$ Five-Year-Plan" period (2016-2020), new investment is planned for improving the interconnection and flexibility of power systems, strengthening renewables accommodation and consumption, expanding new power demand etc. [28]. In this period, the annual growth of installed electricity generation capacity of China's renewables will be $42.5 \mathrm{GW}$ (as shown in Table 4), based on which the total investment in the renewable energy power industry will exceed $\$ 364$ billion [5].

China has been committed to the development of energy projects through the PPP projects in recent years. Among the 1043 PPP projects promulgated by the National 
Table 1 China's total renewable energy power generation $\left(10^{8} \mathrm{kWh}\right)$

\begin{tabular}{|c|c|c|c|c|c|c|}
\hline \multirow[t]{2}{*}{ Province/municipality } & \multicolumn{6}{|l|}{ Year } \\
\hline & 2010 & 2011 & 2012 & 2013 & 2014 & 2015 \\
\hline Beijing & 7.0 & 8.0 & 10.0 & 7.0 & 10.0 & 9.9 \\
\hline Tianjin & 0.0 & 1.0 & 5.1 & 6.0 & 8.0 & 10.3 \\
\hline Hebei & 65.0 & 99.0 & 138.0 & 164.0 & 2177.0 & 1815.3 \\
\hline Shanxi & 43.0 & 48.0 & 81.0 & 98.0 & 101.0 & 124.0 \\
\hline Inner Mongolia & 193.0 & 246.0 & 315.0 & 410.0 & 449.0 & 525.4 \\
\hline Liaoning & 104.0 & 107.0 & 143.0 & 244.4 & 284.0 & 325.5 \\
\hline Jilin & 136.0 & 113.0 & 123.0 & 183.0 & 145.0 & 166.4 \\
\hline Heilongjiang & 55.0 & 59.0 & 70.0 & 98.0 & 99.0 & 114.3 \\
\hline Shanghai & 2.0 & 4.0 & 6.1 & 9.0 & 5.0 & 8.5 \\
\hline Jiangsu & 194.0 & 202.0 & 215.0 & 230.0 & 298.0 & 298.6 \\
\hline Zhejiang & 486.0 & 447.0 & 574.0 & 548.0 & 570.0 & 605.7 \\
\hline Anhui & 37.0 & 31.3 & 41.0 & 45.3 & 77.0 & 74.4 \\
\hline Fujian & 465.0 & 307.6 & 505.0 & 510.0 & 627.0 & 640.9 \\
\hline Jiangxi & 102.0 & 77.0 & 150.0 & 129.0 & 143.8 & 161.0 \\
\hline Shandong & 27.0 & 43.0 & 65.0 & 94.0 & 156.6 & 170.1 \\
\hline Henan & 86.0 & 100.0 & 132.0 & 120.0 & 116.9 & 135.5 \\
\hline Hubei & 1246.0 & 1169.0 & 1382.0 & 1181.0 & 1448.7 & 1410.5 \\
\hline Hunan & 375.4 & 305.0 & 449.0 & 435.0 & 564.0 & 578.0 \\
\hline Guangdong & 611.2 & 650.0 & 796.0 & 813.0 & 986.6 & 1045.6 \\
\hline Guangxi & 475.0 & 415.0 & 525.0 & 464.0 & 662.7 & 635.6 \\
\hline Hainan & 23.0 & 31.0 & 29.0 & 31.0 & 31.5 & 34.2 \\
\hline Chongqing & 144.3 & 147.0 & 211.0 & 179.0 & 245.5 & 255.8 \\
\hline Sichuan & 1139.0 & 1261.0 & 1545.0 & 2024.0 & 2497.4 & 2737.2 \\
\hline Guizhou & 384.0 & 394.0 & 564.0 & 434.0 & 700.8 & 697.4 \\
\hline Yunnan & 819.0 & 1019.0 & 1268.0 & 1669.0 & 2158.6 & 2385.5 \\
\hline Tibet & 16.2 & 18.4 & 16.0 & 17.0 & 28.4 & 26.1 \\
\hline Shaanxi & 74.0 & 95.0 & 84.0 & 79.0 & 130.1 & 121.3 \\
\hline Gansu & 284.0 & 354.0 & 441.0 & 496.0 & 510.0 & 595.2 \\
\hline Qinghai & 363.0 & 368.0 & 472.0 & 455.1 & 450.1 & 500.0 \\
\hline Ningxia & 27.0 & 32.6 & 61.0 & 90.0 & 115.4 & 135.5 \\
\hline Xinjiang Uygur & 126.0 & 150.0 & 190.0 & 237.0 & 331.4 & 356.2 \\
\hline
\end{tabular}

Note: Data sourced from China Electric Power Yearbook (2016)

Development and Reform Commission (NDRC) of China in 2015 , there were 138 with total investment of $\$ 12.7$ billion belonging to the energy sector, as shown in Fig. 4. Among the 138, there were 8 key projects, of which the largest was supported with an investment of $\$ 1.1$ billion [29]. According to statistics from the China PPP integrated information platform of the Ministry of Finance (2017), there were 12287 PPP projects with an investment of $\$ 2130$ billion in 19 industries of mainland China by the end of the first quarter of 2017 [29]. 1729 of those PPP projects are under construction with $\$ 423$ billion investment. Meanwhile, the participation rate of private capital increased steadily. By the end of 2016, the rate had reached $39 \%[30]$.

\subsection{Policy environment}

According to "China's $13^{\text {th }}$ Five-Year Plan (2016-2020) for renewable energy", the new investment in China's renewable energy will reach $\$ 364.8$ billion [31], with an increase of $39 \%$ compared to the " $12^{\text {th }}$ Five-Year" period (2011-2015). By 2020, the total installed capacity of renewable power will be 680 million kilowatts, while the generating capacity will be 1.9 trillion $\mathrm{kWh}$, accounting for $27 \%$ of the total electricity output [32]. To support the 


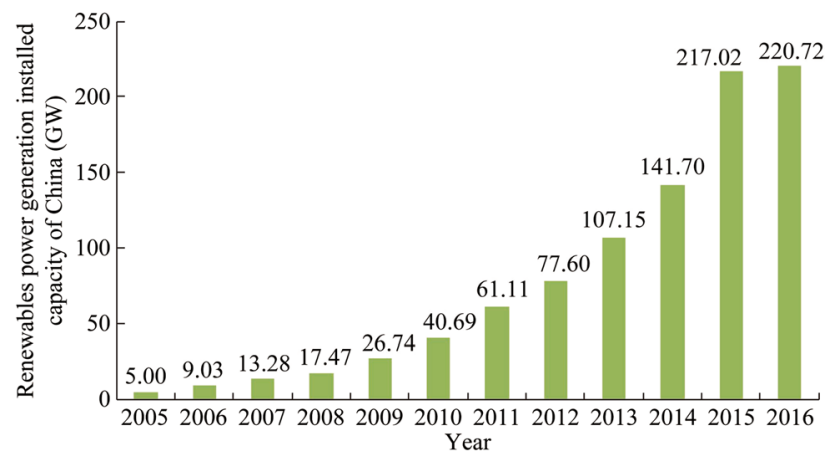

Fig. 1 China's total renewables power generation installed capacity (Source: China Statistical Yearbook 2017)

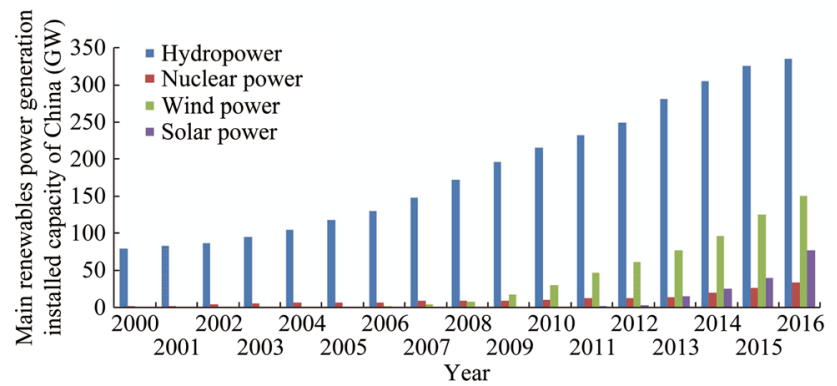

Fig. 2 Main renewables power generation installed capacity of China (Source: China Statistical Yearbook 2017)

Table 2 Changes in investment structure of renewable energy power generation of China (billions of US dollars)

\begin{tabular}{clcc}
\hline Year & Hydropower & Wind power & Photovoltaic and biomass power \\
\hline 2010 & 11.9 & 15.1 & 0.6 \\
2011 & 13.7 & 12.1 & 2.2 \\
2012 & 18.6 & 9.0 & 0.6 \\
2013 & 18.2 & 9.2 & 4.4 \\
2014 & 14.0 & 14.5 & 2.1 \\
2015 & 11.4 & 16.9 & 14.2 \\
2016 & 8.9 & 10.5 & 6.1 \\
\hline
\end{tabular}

development and utilization of renewables, the Ministry of finance has established a special fund for the development of renewables according to the "Renewable Energy Law of the People's Republic of China". The projects supported by the special funds are mainly shown in Table 5 . These special funds for China's renewables development may not encourage the private capital in a direct way, but they have
Table 3 Structural changes of China's renewables finance and investment

\begin{tabular}{llrrr}
\hline \multirow{2}{*}{$\begin{array}{l}\text { Nature of } \\
\text { funds }\end{array}$} & Financing channels & \multicolumn{3}{c}{ Changes (\%) } \\
\cline { 3 - 5 } & & 2012 & 2013 & 2015 \\
\hline $\begin{array}{l}\text { Financial } \\
\text { fund }\end{array}$ & Central finance & 4.3 & 1.3 & 2.2 \\
\multirow{2}{*}{ Social fund } & Local finance & 1.2 & 0.6 & 0.5 \\
& Enterprise self-raised fund & 20.5 & 19.2 & 16.2 \\
& Bank & 56.6 & 56.8 & 49.2 \\
& Stock market and bond & 2.1 & 0 & 0.3 \\
& Venture capital and private & 0.1 & 0 & 0.6 \\
& $\quad$ placement & 14.1 & 20.9 & 30.2 \\
& Public fund & 1.1 & 1.2 & 0.8 \\
\hline \multirow{2}{*}{ Foreign fund } & CDM fund & & &
\end{tabular}

really inspired the interest of private capital to focus on those supported areas.

The special funds focus on supporting those renewables development and utilization areas with great potential and good prospects, such as fossil oil substitution, building heating/cooling, power generation and the like, as shown in Table 6. According to regulations, the procedures for reporting and approving the special funds will follow certain steps, as shown in Table 7. Since then, the key areas of China's renewables investment \& financing have been defined, and the financing and investment procedure has also been standardized. However, the supervision is not in place for implementing these standards.

In the light of the relevant regulations, the special funds for China's industrial development include the following two types: gratuitous allocation and the subsidized loan $[33,34]$, as shown in Table 8. Neither the gratuitous allocation nor the subsidized loan will be used independently in the system under normal conditions.

\section{Analysis and discussion}

A SWOT map is used to help discuss four dimensions of advantage, disadvantage, chance and challenge, as shown in Fig. 5.

\subsection{Strength analysis}

The first advantage is that China has a wide range of renewables and an enormous natural endowment of energy resources [35-37]. The mean annual solar radiation is 6000 $\mathrm{MJ} / \mathrm{m}^{2}$ per year and direct sunshine is over $2200 \mathrm{~h} / \mathrm{a}$ in China. The total reserves of wind energy at the height of 10 $\mathrm{m}$ are $3226 \mathrm{GW}$ of which the technically and economically 


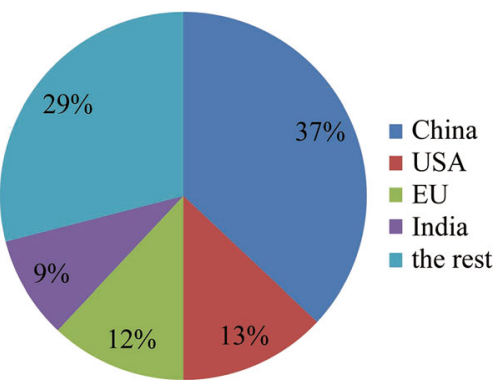

Fig. 3 Key markets of the renewables growth in 2021 (Source: IEA Medium-Term Renewable Energy Market Report 2016)

Table 4 Investment objectives from the " $13^{\text {th }}$ Five-Year-Plan" (2016-2020)

\begin{tabular}{|c|c|c|}
\hline \multirow[t]{2}{*}{ Renewable energy } & \multicolumn{2}{|c|}{ Forecast of the total value for 2020} \\
\hline & $\begin{array}{l}\text { Newly installed } \\
\text { capacity }(\mathrm{GW})\end{array}$ & $\begin{array}{l}\text { Newly added } \\
\text { investment (billion } \$ \text { ) }\end{array}$ \\
\hline Hydropower & 60 & 72.9 \\
\hline Wind power & 80 & 102.1 \\
\hline Solar photovoltaic & - & 145.9 \\
\hline Biomass power and other & - & 43.8 \\
\hline
\end{tabular}
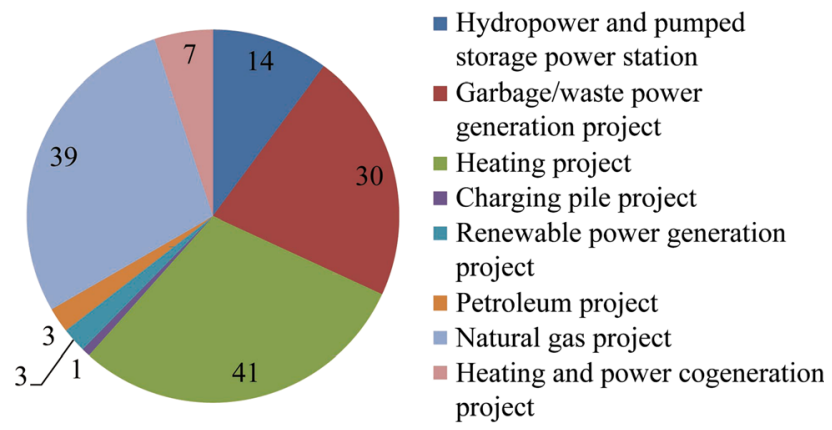

Fig. 4 Composition of 138 PPP projects (Source: China Electric Power Yearbook 2016)

exploitable potential could be approximately $1000 \mathrm{GW}$. The reserves of hydropower resources are $676 \mathrm{GW}$ theoretically, and the exploitable hydropower could be 380 $\mathrm{GW}$. With respect to biomass resources, roughly 400 million tons of agricultural residues per year and 350 million tons of forestry residues per year are available for energy utilization and application [37].
Table 5 List of funds supporting areas

\begin{tabular}{ll}
\hline $\begin{array}{l}\text { Serial } \\
\text { number }\end{array}$ & Classification \\
\hline 1 & $\begin{array}{c}\text { Scientific and technological research, standard setting } \\
\text { and demonstration projects for the development and } \\
\text { utilization of renewable energy } \\
\text { Renewable energy utilization projects in rural areas and } \\
\text { pastoral areas }\end{array}$ \\
3 & $\begin{array}{l}\text { Independent power system construction for renewable } \\
\text { energy in remote areas and on islands } \\
\text { Resource exploration, evaluation and related } \\
\text { information system construction of renewable energy } \\
\text { Localized production promotion of renewables } \\
\text { development and utilization equipment }\end{array}$ \\
\hline
\end{tabular}

Note: Data sourced from Ministry of Finance (2015)

The second advantage is that China has strong product manufacturing capabilities which could guarantee the development of a renewables industry [38, 39]. Chinese enterprises have been building many hydropower projects overseas. At the same time, wind power and solar energy are focusing on expansion in international markets after a short-term, unconventional and rapid development [40]. China has mature renewable energy technologies, powerful equipment manufacturing capacity and adequate financial support.

The third advantage is that China has made great progress in production technology such that the technology cost decreases year by year [41, 42]. In particular, the technologies and key equipment for photovoltaic and wind power can match the pace of current development anywhere in the world. As far as cost is concerned, the price of using solar power today is just $1 / 6$ of that of 10 years ago when the same output of electricity is produced. In addition, the average dollar capital expenditure per megawatt for wind power in 2016 dropped by more than 10 percent compared to the previous year [42].

\subsection{Weakness analysis}

First, the cost of renewable energy is still higher than that of traditional energy (e.g. thermal power) currently [43]. The high cost of renewables is a matter of great concern for private capital. The high cost problem cannot be solved in the short run. In addition, the renewable curtailment problem adds to the misfortunes of Chinese private investors. Specifically, if there were no concern about the power curtailment of renewables demonstration projects in China, it would definitely be possible for renewable energy generation of 2800 annual utilization hours of installed capacity to be competitive with thermal power generation. 
Table 6 Key areas supported by special funds

\begin{tabular}{lll}
\hline $\begin{array}{l}\text { Serial } \\
\text { number }\end{array}$ & Field & Popularization and application \\
\hline 1 & $\begin{array}{c}\text { Fossil oil } \\
\text { substitution } \\
\text { Building } \\
\text { Heating/cooling }\end{array}$ & Bioethanol fuel, biodiesel \\
2 & $\begin{array}{c}\text { Solar energy, geothermal energy } \\
\text { Wind energy, solar energy, } \\
\text { ocean energy }\end{array}$ \\
4 & $\begin{array}{c}\text { Other supporting priorities formulated by the national } \\
\text { renewable energy development and utilization } \\
\text { program }\end{array}$ \\
\hline
\end{tabular}

Secondly, the construction of renewable energy infrastructure has not yet completely caught up with demand $[44,45]$. Wind power resources, for example, are mainly concentrated in Inner Mongolia, northeast and northwest regions of China, and in the resources are much more abundant in winter in those places. However, the thermoelectric units should be switched on first to ensure heating supply in these areas. Since the grid construction lags, wind power units will have to make way for heat supply units, resulting in the fact that wind power cannot be accommodated or sent to the south of China through the power grid channel. Clearly, the power grid of China is not ready for the accommodation of renewables under current circumstances.

Thirdly, China's energy sector is changing from being capital-intensive to technology-intensive [46]. However, Chinese private enterprises are less capable of independent innovation [47]. The core technologies that most Chinese enterprises are using are from foreign countries because of some unavoidable issues such as the weakness of basic research, the low level of innovation, the lack of a technical research support platform, the absence of a technology development route and the insufficiency of a continuous $\mathrm{R} \& \mathrm{D}$ investment plan.

Finally, China's renewable energy strategy has not yet reached a common consensus. This confuses those privatecapital enterprises [48]. Currently, the whole of society does not completely realize the strategic importance of developing renewable energy although the renewable energy sector is one of the national strategic emerging industries [49]. The energy sector of China pays more attention to immediate interests, local interests, or departmental interests. If the renewable energy industry could be treated seriously as a strategic emerging industry for the long term, there would be no such problems [50].

\subsection{Opportunity analysis}

First, international cooperation in such new situations can promote the influx of private capital into the renewable energy industry. China unveiled the principles, framework, and cooperation priorities and mechanisms in its "Belt and Road Initiative" (B\&R) [51, 52]. The connectivity of infrastructure is not only a significant priority for implementing the B\&R, but also an important support for improving trade facilitation and establishing a high-standard free trade area network. The contradiction is the conflict between strong infrastructure demand and

Table 7 Procedure for reporting and approving the special funds

\begin{tabular}{|c|c|c|c|}
\hline $\begin{array}{l}\text { Step } \\
\text { number }\end{array}$ & Department & Action & Behavior basis \\
\hline 1 & $\begin{array}{l}\text { Renewable energy centralized } \\
\text { management department and } \\
\text { Finance Department of the State } \\
\text { Council }\end{array}$ & $\begin{array}{l}\text { Organizing experts to prepare and publish the } \\
\text { annual special funds declaration guidelines }\end{array}$ & $\begin{array}{l}\text { According to the needs of the National } \\
\text { economic and social development and the } \\
\text { National renewables development and } \\
\text { utilization plan }\end{array}$ \\
\hline 2 & $\begin{array}{l}\text { Organization or individual of will } \\
\text { and ability }\end{array}$ & $\begin{array}{l}\text { Submitting the declarations to the local } \\
\text { administrative departments of renewable } \\
\text { energy sources and the local finance } \\
\text { departments respectively }\end{array}$ & $\begin{array}{l}\text { According to the annual special funds } \\
\text { declaration guidelines }\end{array}$ \\
\hline 3 & $\begin{array}{l}\text { Local administrative department } \\
\text { of renewable energy sources } \\
\text { and local finance department }\end{array}$ & $\begin{array}{l}\text { Reporting to the renewable energy centralized } \\
\text { management department and the Finance } \\
\text { Department of the State Council }\end{array}$ & $\begin{array}{l}\text { According to the administrative approval } \\
\text { process }\end{array}$ \\
\hline 4 & $\begin{array}{l}\text { Renewable energy centralized } \\
\text { management department and } \\
\text { Finance Department of the State } \\
\text { Council }\end{array}$ & $\begin{array}{l}\text { Entrusting the relevant agencies to assess the } \\
\text { application materials, or organizing experts to } \\
\text { review the qualification }\end{array}$ & According to the declaration status \\
\hline 5 & Local finance department & $\begin{array}{l}\text { Allocating the special funds to the eligible } \\
\text { organization or individual with timely and } \\
\text { sufficient funding }\end{array}$ & $\begin{array}{l}\text { According to the evaluation result in } \\
\text { accordance with the established procedures }\end{array}$ \\
\hline
\end{tabular}


Table 8 Use of special funds

\begin{tabular}{|c|c|c|c|}
\hline No. & $\begin{array}{l}\text { Purpose of } \\
\text { use }\end{array}$ & Object & Content and requirements \\
\hline 1 & $\begin{array}{l}\text { Gratuitous } \\
\text { allocation } \\
\text { form }\end{array}$ & $\begin{array}{l}\text { Renewables development and utilization projects with } \\
\text { weak profitability and strong public welfare }\end{array}$ & $\begin{array}{l}\text { The one meeting the standard setting could be fully funded } \\
\text { by the State, while the project undertaker (organization or } \\
\text { individual) shall provide its own counterpart funds which } \\
\text { should be more than the amount of the gratuitous } \\
\text { allocation subsidy funds }\end{array}$ \\
\hline 2 & $\begin{array}{l}\text { Subsidized } \\
\text { loan form }\end{array}$ & $\begin{array}{l}\text { Renewables development and utilization projects included } \\
\text { in the National renewable energy industry development } \\
\text { guidance directory and meeting the credit conditions }\end{array}$ & $\begin{array}{l}\text { Only if the bank loans have been in place and the interest } \\
\text { paid by the project undertaker has been paid, can the } \\
\text { subsidized loan be arranged. The discount period is } 3 \\
\text { years, and the annual interest rate is less-than-or-equal-to } \\
3 \%\end{array}$ \\
\hline
\end{tabular}

Source: authors

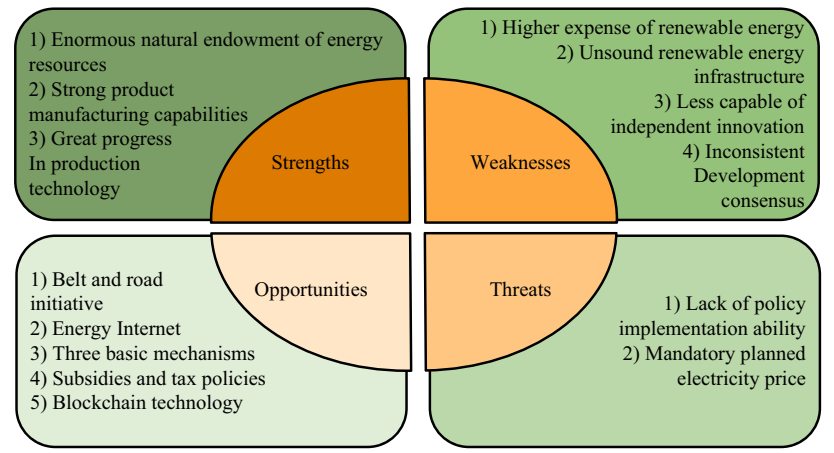

Fig. 5 SWOT analysis model of private capital entering renewable market

insufficient construction funds. It is the rapid development of the PPP mode in solving Chinese funding gaps that has become the most ideal way to resolve the contradiction in recent years [53].

Second, the "Guiding Opinions on Promoting the Development of 'Internet Plus' Smart Energy" promulgated by three departments including the NDRC, on 29th February, 2016, puts forward that "Internet Plus" Smart Energy (Energy Internet) will enable complex coordination between suppliers and users to facilitate future energy generation, transportation and financing [54]. On the one hand, China will promote intelligent production of renewables, and encourage the construction of intelligent wind power plants, intelligent photovoltaic power stations and other facilities as well as smart cloud platforms based on the Internet. On the other, China will also design a realtime subsidy mechanism for renewables, develop large energy data service applications, push forward the key technologies of the Energy Internet, and build an international leading standard system for the Energy Internet.

Third, the Chinese Government has implemented 3 mechanisms to ensure institutional confidence in private capital accessing the renewable energy power generation industry: 1) the "Protective Full Acquisition System for Renewable Energy" [55]; 2) the "Carbon Trading Scheme" [56]; 3) the "Tradable Green Certificate System" $[56,57]$. Through these mechanisms, the mode of "Differential Subsidy" will be gradually transformed into a new mode of "Quota Subsidy + Green Certificate Income".

Fourth, renewables development in China cannot be independent of tariff subsidies and preferential tax policies implemented by the Chinese Government [58]. The financial subsidies mainly coming from the Energy Renewable Development Fund (RDF) will be offered by the finance sector to compensate for the price differences These form the shortfall brought about by the price exceeding the desulfurization coal-fired power benchmark on-grid price.

Fifth, blockchain technology provides a way to further incentivize and account for renewable energy development $[59,60]$. A blockchain is a distributed database that is used to maintain a continuously growing list of records. If China can improve the operation mechanism and the credit system, and realize effective transaction management of energy products, the energy blockchain will certainly create new market demand with respect to energy accommodation and industrial development.

\subsection{Threat analysis}

On the one hand, the lack of policy implementation ability is one of the obstacles to the active participation of private capital [61]. Some of those industrial policies failed to execute the policy function at the actual operational level, although the Chinese government offers unwavering financial support for renewable energy generators even as other countries scale back or restructure similar support programs. Therefore, the bottleneck of policy and financing is the most difficult aspect for Chinese private capital entering the market. In addition, excessive reliance on industry support policies created more problems for the 
renewables than they have solved. This itself puts pressure on the Government. Although great efforts have been continually made in this regard, the demand-supply gap of renewables subsidies was as much as 8.75 billion dollars by the end of 2016.

On the other hand, the electricity price is also an obstacle to the industrialization of renewable energy power generation $[62,63]$. The development of renewable energy in China is more obviously restricted by electricity pricing. However, the renewable energy industry of China as a whole is still in its infancy, and most of the enterprises are still a long way away from making any kind of profit. If there is no reasonable price formation mechanism, it is difficult for private capital to make scientific investment and production decisions. This will affect the morale of Chinese private capitalists. Therefore, the hidden danger of renewable energy development in China is the restriction of the current electricity price policy.

\section{Scheme design}

\subsection{Ideal financing model}

It is difficult for investors to meet their own capital needs due to the huge demand for investment in renewable energy production [31, 35]. To solve the problem of investment and financing, a rational way is the ideal financing model, as shown in Fig. 6.

1) At the initial stage (Immature Period), the main investment method is venture capital, and the sources of funds are mainly private capital and various venture capital institutions.

2) The credit fund and the private equity investment (PE) turn into the main fund-raising channels right after the industry reaches the developing stage (Growth Period) and makes profits, including the venture capital, political funding and private capital.

3) At the stabilizing stage of the industry (Mature Period), credit funds can still be used by enterprises,

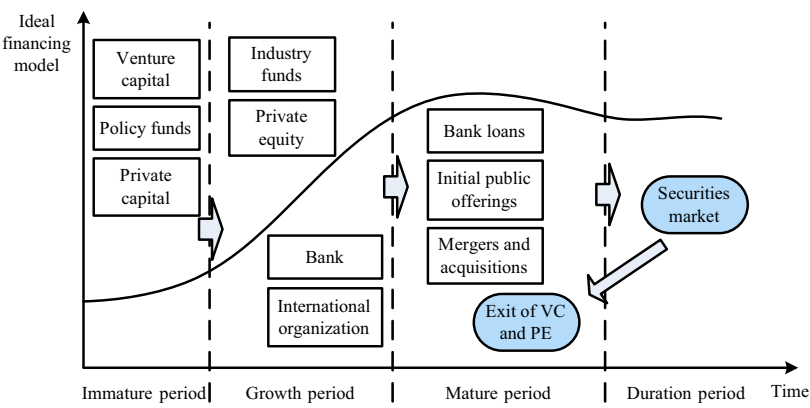

Fig. 6 Ideal financing model for renewable industry while enterprises can make full use of the securities market for direct financing through initial public offerings (IPO) as many enterprises in the industry meet the listing requirements.

In view of the current development situation, China's renewable energy industry needs a market of high maturity with a valid financing mechanism and effective policy guidance to achieve the ideal financing model. Additionally, the financing programs vary for different renewable energy power generation technologies.

\subsubsection{Wind power generation}

In the " $13^{\text {th }}$ Five-Year-Plan" period (2016-2020), the main task of Chinese wind power is to orderly construct a large-scale wind power base in Northeast, Central North and Northwest China, and promote offshore wind power development steadily. Most striking amidst all these impressive accomplishments of renewable power generation industry has been wind power's rapid development, which gives the wind power sector a financing advantage and investment value. Policies also strongly support and promote wind power, so China's wind power sector financing should be highly dependent on bank loans as well as private capital since the wind power generation industry is in the Growth Period in China.

\subsubsection{Photovoltaic power generation}

During 2016-2020, the task of Chinese photovoltaic power is to comprehensively promote the distributed photovoltaic generation and "Photovoltaic + " integrated utilization projects, and advance large-scale photovoltaic power station construction. China's photovoltaic power generation market has been developing rapidly so far, but photovoltaic power generation is a technology-intensive and capital-intensive industry. This makes the demand for funds pretty large. Banks and private capital are wary of lending to the photovoltaic power industry just as with the biomass power industry since the photovoltaic power generation industry of China has just entered the developing phase of the Growth Period.

\subsubsection{Biomass power generation}

In the period of 2016-2020, the task of Chinese biomass power is to accelerate the development of biomass technology and promote technology application demonstration projects. The equipment for biomass power generation needs a large amount of capital investment, so the main economic entities of biomass power generation are still large state-owned enterprises. In the case of difficulty in 
getting to profitability, bank credit funds and private capital market funds are reluctant to enter the biomass power generation industry. Political funding and venture capital evidently may provide the financial capital needed to the immature period development of biomass power generation.

\subsubsection{Hydropower generation}

In the " $13^{\text {th }}$ Five-Year-Plan" period (2016-2020), the task of Chinese hydropower is to actively promote the construction of large hydropower bases. The installed capacity of China's hydropower ranks first in the world. However, the capital structure of hydropower projects is irrational. At present, bank loans and self-financing are widely used, accounting for nearly $80 \%$ of the total investment, while bond finance and other financing methods are rarely used. The current hydropower structure makes it difficult to reduce financing costs, and hence venture capital, political funding and private capital will be able to play an important role in constructing China's hydropower generation.

\subsection{Public-private partnership}

In 2010, the State Council of China issued a document to outline the country's plan to foster the well-being of private investment, and since then the NDRC has been actively encouraging private capital to take part in the restructuring of China's financial institutions. Based on the above analysis, private capital is capable of participating in the development of China's energy industry. Particularly from the point of view of sustainable development of energy and environment, PPP projects will be applied in a wide range of renewables industry fields, as shown in Fig. 7. The broad definition of PPPs include several modes such as Build-Operate-Transfer (BOT), Build-Own-Operate-Transfer (BOOT), Build-Own-Operate (BOO), Build-

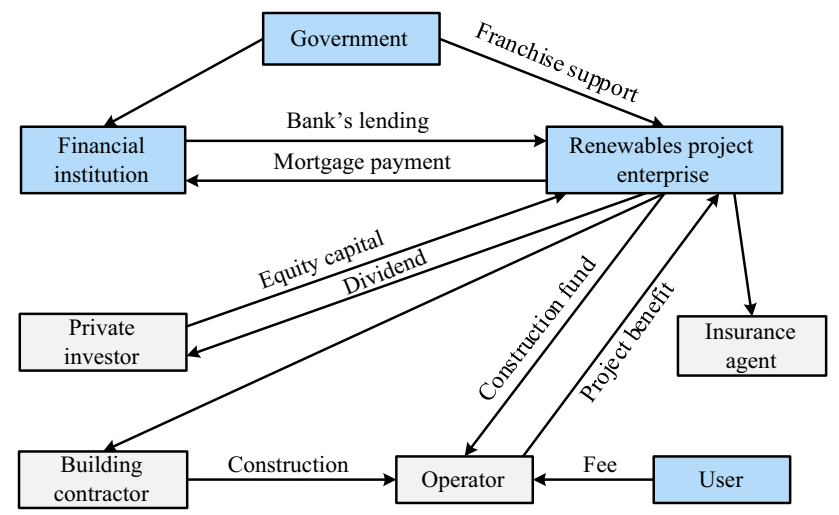

Fig. 7 Public-private partnerships for renewable industry
Lease-Transfer (BLT), Build-Transfer (BT), TransferOperate-Transfer (TOT), TOT + BOT (TBT) and PrivateFinance-Initiative (PFI). The successful promotion of a PPP project should basically define the specific method for the government's participation, and adopt a certain mode of PPP implementation.

At present, insufficient policy implementation ability and the mandatory planned electricity price prevent effective investment and financing from pouring into China's renewables. In view of the lack of policy implementation ability, the Chinese government should establish fair competition examination rules, improve the authority of the anti-monopoly law enforcement agencies, and unify the administration, the legislation, the judicature as well as public education [61]. With respect to the mandatory planned electricity pricing, China should continue to promote the reformation of the electric power system, not only by liberating the electricity retail markets and constructing provincial power spot markets, but also by forming energy market pricing combined with some secondary markets, such as the Tradable Green Certificates market and the carbon trading market $[62,63]$. If these two problems are properly solved, China's private capital will have the chance to choose the suitable PPP mode.

\subsubsection{BOT or BOOT}

BOT or BOOT is a form of project financing, wherein a private entity receives a concession from the private or public sector to finance, design, construct, and operate a facility stated in the concession contract. This enables the project proponent to recover its investment, operating and maintenance expenses in the project. If the preferential policy implementation is in place, the BOT mode can be adopted in hydropower projects in China.

\subsection{2 $\mathrm{BOO}$}

In a BOO project, ownership of the project usually remains with the project enterprise. Therefore, private enterprise gets the benefits of any residual value of the project. This framework is used when the physical life of the project coincides with the concession period. A BOO scheme involves large amount of finance and long payback period. When the system is sound and the policy is in place, biomass power generation projects in China can use BOO mode for financing and operation.

\subsubsection{BLT}

BLT is a contractual arrangement whereby the private enterprise undertakes the financing and construction of an infrastructure project and upon its completion hands it over 
to the government on a lease arrangement for a fixed period, after the expiry of which ownership of the project is automatically transferred to the government agency. Based on the analysis of the current situation of renewable energy resources in China, the BLT mode is not suitable for largescale promotion at present.

\subsubsection{BT}

BT is a contractual arrangement whereby the private enterprise undertakes the financing and construction of an infrastructure project and after its completion hands it over to the government. The government agency will reimburse the total project investment, on the basis of an agreed schedule. To attract international capital as well as private capital, and accelerate technology transfer, especially for the countries along the B\&R, the BT mode can be applied to wind power and solar power projects.

\subsubsection{TOT}

TOT usually refers to one of the international project financing modes. The government or state-owned enterprises will offer a compensated transfer of a certain period of ownership or management rights of constructed projects to private investors. The private investors should operate and manage those projects by themselves. The operation and management will not stop until the investors recover all their investment and receive reasonable returns within the agreed period. After the expiration of the contract, the investors will return the projects to the government or the original enterprises. There is no need to experience the construction process, and the renewable energy enterprises, such as large wind power projects, photovoltaic power projects, biomass power projects, etc., can avoid the risks in the engineering project construction phase.

\subsubsection{PFI}

PFI is a way of creating PPPs by funding public infrastructure projects with private capital. PFI is a procurement method which uses private sector investment to deliver public sector infrastructure and/or services according to a specification defined by the public sector. It has also been used simply to place a great amount of debt "off-balance-sheet". As far as the current development trends are concerned, the PFI mode is more suitable for biomass power generation and biogas power generation projects in some parts of china.

\subsection{Patterns of distributed energy resource}

The aforementioned financing \& investment schemes for private capital are mostly designed for large-scale centralized renewables projects. However, the problem is how do the private investors enter the field of renewable energy if they are short of money and unwilling to take risks? Even taking mixed ownership, private enterprises are also too disadvantaged and weak to have the discourse power and discourse right in cooperation with state-owned enterprises. This makes a number of private enterprises overcautious when approaching the energy sector [64]. It is skillful to resort to some other tactics, for example investing in the distributed energy resources (DER) projects, as shown in Fig. 8.

Distributed generation, viz. distributed energy, on-site generation or district/decentralized energy, is generated or stored by a variety of small, grid-connected devices referred to as distributed energy resource system. It is rather remarkable that China has increased its support for DER projects since 2011. The government has promulgated a number of favorable policies for the comprehensive utilization of energy in recent years, especially for the use of distributed energy resources at the national level (Note: Such as the "Guiding Opinions on the Development of Natural Gas Distributed Energy Resource", "Interim Measures for the Management of Distributed Generation", "Circular on Further Implementing the Relevant Policies on Distributed Photovoltaic Power Generation", a number of incentives for decentralized photovoltaic power generation with self-produced and self-consumed renewable power products). With respect to the private sector, their decision to invest in renewable projects is strongly influenced by the project risks, payment mechanism and long term of the contract. Before entering the renewable energy industry, private investors should take into account some important factors, such as the expected return, the property right, the operation mechanism and the expert professionals [65-67]. DER projects constructed and operated by private enterprises can alleviate any financial embarrassment of the government in the initial investment due to the pooling of private capital, and have great policy advantages under the strong support of central, provincial and municipal governments. With the rapid development of the economy and technology and the improvement of socio-economic conditions, it is inevitable for distributed renewable energy, as the new resource technology in the Blue Ocean Strategy of China, to maintain sustained and stable growth by expanding investment $\&$ financing channels and increasing the number of individual private investors. Consequently, the introduction of private capital into DER projects will become an inexorable trend for the construction and development of the renewables industry. 


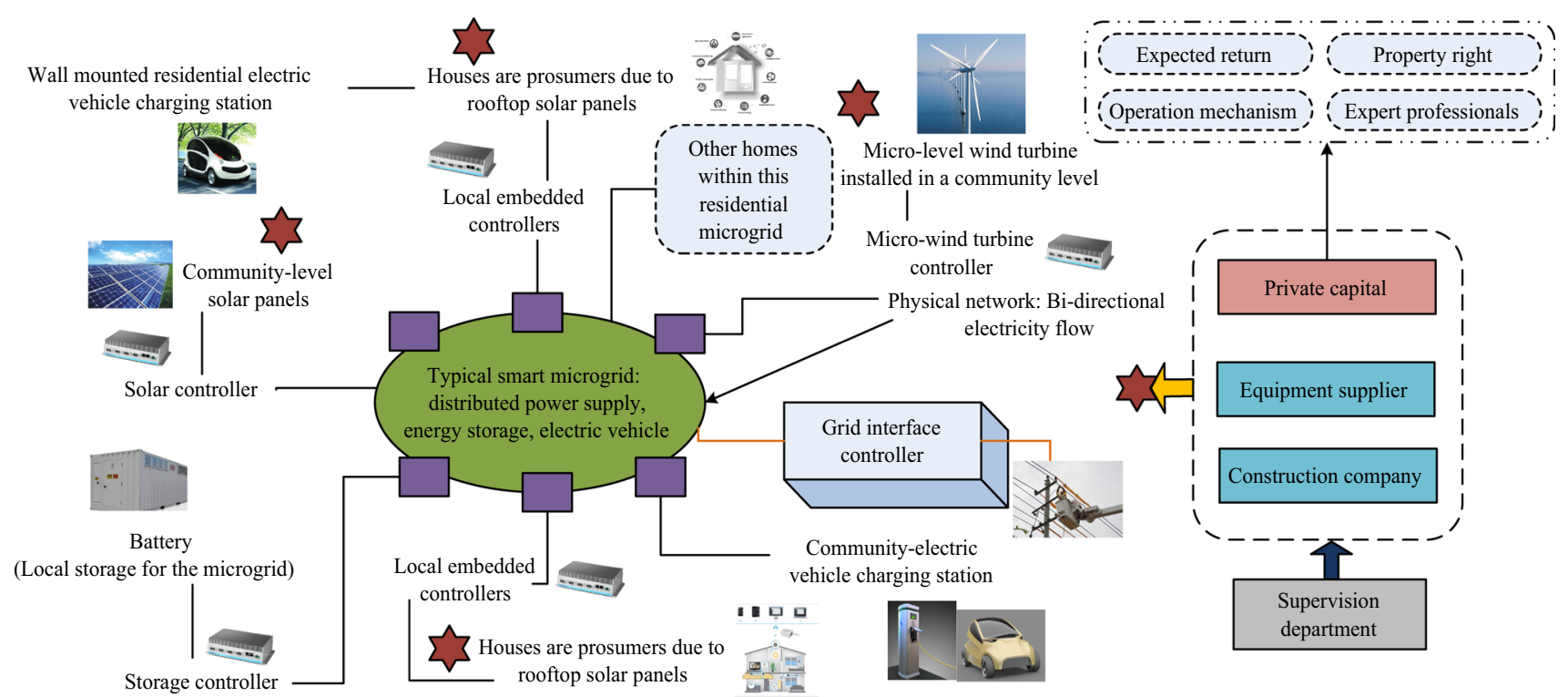

Fig. 8 Distributed energy resources for private capital

Take the rooftop photovoltaic power generation system for example. The system has a long working life with zero fuel cost and negligible maintenance cost but requires huge initial investment. Hence its cost depends on the capacity of the system, the unit-price of the equipment, and the expense of installation and construction. The capacity of the system is related to the overall investment, and it is bound up with the roof of the user and the previous budget. The general capacity of a rooftop photovoltaic power generation system is mainly $3-5 \mathrm{~kW}$, which makes, by our informal count, the total investment 4377-7295 dollars. According to our investigation, there are three main parts of the income from investment in the rooftop photovoltaic power generation system for a private investor. The first part is the income through the state subsidies. The state subsidy for distributed photovoltaic power stations is 6.13 cents per kWh (including tax) with a subsidy period of 20 years. The second part is the savings from self-produced electricity. The self-produced solar photovoltaic power, whether it is for satisfying self-consumption or for selling to others, is able to be applied to saving money by reducing electricity bills. In other words, the system operates itself just like a virtual power plant. The third part is the sales earnings in commercial transactions. The private investors can receive proceeds from the sale of electricity by selling the distributed solar photovoltaic power to the power grid corporation at the benchmarking of electricity price of the desulfurization coal-fired units. If one private investor is willing to build such a system of $5 \mathrm{~kW}$ installed capacity with an investment of roughly $\$ 7300$, he/she is more than capable of recovering costs in about 6-7 years and getting nearly $15 \%$ yield in the next 13 years in China. The basic data is business information which is not convenient to publish. The result is also provided by the marketing department of 3 enterprises in Shanghai. These data are to support the research basis of the paper, so the calculation formula is not discussed as key content.

\section{Conclusion and recommendation}

\subsection{Research conclusions}

In summary, here are the following conclusions:

1) There are many strengths and opportunities for private capital investment in the renewable energy industry in China. The industrial development of renewables is a pressing matter. When the renewable energy industry matches its internal advantages to its external opportunities, it will create core competencies in meeting the basic requirements of China's energy sector. More importantly, the renewable energy industry should promptly overcome the internal weaknesses and deal with the external challenges at the same time. The total investment in those renewables projects including solar power and wind power has suffered a sharp decline, and unfortunately, the trend of investment shrinking is likely to continue. Once the correction period occurs, the investment shrinkage will be reversed. The shrinkage is attributed to external causes at best, while the real reasons for the shortage of funds in the renewable energy market are still the internal ones. Investors suffer from not only the uncertainty about the market outlook and the policy options, but 
also the irregularity of the industrial consolidation and adjustment period.

2) If China can overcome the defects and obstacles in a reasonable and orderly fashion, the investment and financing problems of China's renewables industry will be mostly solved. With the advance of supply-side structural reform and the new round of electric power system reform, along with the continuous improvement and optimization of electricity sale-side market liberalization, private capital entering the Chinese renewable energy market will bring great incentives for the entire energy industry. Meanwhile, it appears that the distributed energy resources pattern is supposed to be a useful way of entering the renewable industry for private capital. To achieve development objectives, China must overcome the lack of policy implementation ability and the mandatory planned electricity pricing for the renewables sector. If both of the aforementioned conditions are met, those Chinese enterprises with private capital entering the energy sector will lead to the Weever Effect, thereby stimulating the development of the energy sector. However, as one can see, the involvement of private capital does not represent the marketization of energy prices. As a special commodity, energy, especially the renewables, has a bearing on the adjustment of complicated and extensive interests, while a reasonable energy structure must be the result of an equilibrium game of multiple stakeholders.

3) When private capital approaches the renewable energy market, investors should pay attention to two problems: one is how to select the sub-industry of the renewable energy sector, and the other is how to choose the appropriate operation mode of publicprivate partnerships. Although bank credit, government funds and venture capital have played a necessary supporting role in the process of investment and financing in China's renewable energy industry, the support from the stock and bond market for renewable energy industry is still pretty inadequate. Furthermore, with the introduction of detailed rules for the implementation of private investment in the energy sector, the pace of private capital entering the energy sector will be further accelerated in the future, and the areas and fields being allowed for entry will be much wider and more diversified. It is noted that great efforts must be made by both Chinese enterprises and the Chinese government. The government must design a creative and innovative security system actively, establish some new funds for the renewable and sustainable energy legitimately, encourage private capital injection by selecting the correct financing mode positively, and promote stock market development to provide comprehensive and reasonable financial support for renewables.

\subsection{Policy recommendations}

The phenomenon of private capital's flocking cooperation has not yet appeared in China's energy sector. For more extensive and in-depth cooperation, there are certain misgivings for social/private capital. Those misgivings cannot be allayed mostly because of the long-standing approval mechanism, the wasteful duplication of functions and the unmeasurable uncertainty of the authorities. They are also the main reasons why many of China's energy PPP projects have failed in the past. To build a mature and advanced operation environment for renewables PPP projects, the Chinese government must adjust its functional positioning more effectively, and form some flexible and effective PPP modes suitable for China's current development situation in the process of practical work, institutional change and international cooperation. Some earnest endeavors must be made by the government as soon as possible to improve the reform of the financial system by further liberating the financial and insurance market, optimizing the finance and investment system by increasing the openness of the financial sector, and ameliorate the operational environment for renewables by creating a good financing space for the projects.

Open Access This article is distributed under the terms of the Creative Commons Attribution 4.0 International License (http:// creativecommons.org/licenses/by/4.0/), which permits unrestricted use, distribution, and reproduction in any medium, provided you give appropriate credit to the original author(s) and the source, provide a link to the Creative Commons license, and indicate if changes were made.

\section{References}

[1] Energy Storage of China Network (2017) Current situation of wind power in European power grid. http://www.escn.com.cn/ news/show-401271.html. Accessed 2 March 2017

[2] China Environment (2017) Report released by the International Renewable Energy Agency (IRENA): there were 9.8 million jobs in the global renewable energy sector. http://hbw. chinaenvironment.com/zxxwnr/index.aspx? nodeid=178\&page $=$ ContentPage \&contentid=93250. Accessed 7 June 2017

[3] India Environment Portal (2017) Global trends in renewable energy investment 2017. http://www.indiaenvironmentportal. org.in/content/441406/global-trends-in-renewable-energyinvestment-2017/. Accessed 4 June 2017

[4] Ministry of Commerce of the PRC Network (2017) China ranking first in the list of the most attractive countries for renewable energy investment. http://www.mofcom.gov.cn/ article/i/jyjl/m/201705/20170502578658.shtml. Accessed 19 May 2017 
[5] Sina Finance (2017) China becoming the most attractive country with respect to renewable energy investment. http://www.sohu. com/a/141165033_219984. Accessed 17 May 2017

[6] Rajnish Ahuja (2016) Functionality of India's renewable energy policy—in wake of $175 \mathrm{GW}$ by 2022. http://www.altenergymag. com/article/2016/10/functionality-of-india\%20\%20-renewableenergy-policy-in-wake-of-175-gw-by-2022/24853. Accessed 13 Oct 2016

[7] NetEase Finance (2016) China has $\$ 9$ billion funding gap to overcome for the renewable energy industry. http://money.163. com/16/1019/18/C3OSMMSA002580S6.html. Accessed 19 Oct 2016

[8] IRE Agency (2012) Financial mechanisms and investment frameworks for renewables in developing countries. International Renewable Energy Agency. http://www. indiaenvironmentportal.org.in/content/369336/financialmechanisms-and-investment-frameworks-for-renewables-indeveloping-countries/. Accessed 12 Jan 2012

[9] Nelson D, Shrimali G (2014) Finance mechanisms for lowering the cost of renewable energy in rapidly developing countries. Clim Policy Initiat. http://www.indiaenvironmentportal.org.in/ content/386884/finance-mechanisms-for-lowering-the-cost-ofrenewable-energy-in-rapidly-developing-countries/. Accessed 1 Jan 2014

[10] Jørgensen S, Kort PM (1997) Optimal investment and finance in renewable resource harvesting. $\mathrm{J}$ Econ Dyn Control 21(2-3):603-630

[11] Nie PY, Chen YH, Yang YC et al (2016) Subsidies in carbon finance for promoting renewable energy development. J Clean Prod 139:677-684

[12] He LY, Zhang LH, Zhong ZQ et al (2018) The effect of environmental uncertainty, external financing and policy on renewable energy investment. Resour Sci 40(4):748-758

[13] Chang YM (2017) Problems and countermeasures in the financing of biomass energy industry. West Finance Account 12:55-57

[14] Nie LS (2017) SWOT analysis on photovoltaic power generation projects based on PPP financing mode. Dev Guide Build Mater 15(11):30

[15] Manos B, Bartocci P, Partalidou M et al (2014) Review of public-private partnerships in agro-energy districts in Southern Europe: the cases of Greece and Italy. Renew Sustain Energy Rev 39(6):667-678

[16] Emmanuel Cedrick BZ, Long W (2017) Investment motivation in renewable energy: a PPP approach. Energy Procedia 115:229-238

[17] Zhang T, Meng K, Wu H (2017) Thinking and suggestions on the application of PPP in small hydropower industry in Chinalearning from the Turkey market. Small Hydro Power 4:44-47

[18] Wang ZY, Li Y (2016) Strategy of China's hydropower enterprises to deal with the reform of electricity market. Contemp Econ 30:44-46

[19] Liu SW, Zhao XL, Yan FG (2016) The impact of wind power priority dispatch on power system energy intensity and economic cost. Electr Power 49(9):130-136

[20] Tan QL, Wang RW, Pan XX et al (2017) Research on supply chain model of biomass power generation under fuzzy supply. China Soft Sci 2:123-131

[21] Wang L (2016) Application of distributed PV generation in grid-connection during the construction of power marketing system. Low Carbon World 34:63-64

[22] Worldwatch (2017) China on pace to become global leader in renewable energy. http://www.worldwatch.org/node/5497. Accessed 28 May 2017

[23] International New Energy Network (2017) Renewable energy capacity in the world soaring to a greater height in 2016. http:// newenergy.in-en.com/html/newenergy-2291589.shtml. Accessed 10 Apr 2017

[24] China Power News Network (2015) Power grid investment over power supply investment, distribution network being the focus of investment. http://www.cpnn.com.cn/zdzgtt/201503/ t20150304_785645.html. Accessed 4 Mar 2015

[25] Dong WJ, Qi Y (2014) Annual review of low-carbon development in China. https://www.brookings.edu/wp-content/uploads/ 2016/06/renewable-energy-investment-dong-qi.pdf. Accessed 14 May 2015

[26] Gao H (2016) China's investment in renewable energy ranking world no. 1 for two consecutive years. World Environ 1:34-35

[27] Bai WT (2017) New journey of new energy. Electr Age 2:28-29

[28] Huang XQ, Wang F, Tan YH et al (2016) Coordinated scheduling of electric vehicles and renewable generation considering vehicle-to-grid mode. Chin J Eng Des 23(1):67-73

[29] China Economic Net (2017) PPP projects of China with an investment of $\$ 2130$ billion. http://www.ce.cn/xwzx/gnsz/gdxw/ 201705/02/t20170502_22472529.shtml. Accessed 2 May 2017

[30] Global Energy Conservation and Environmental Protection Network (2017) Ministry of finance: participation rate of private social in PPP projects is increasing. http://www.gesep.com/ news/show_81_357144.html. Accessed 20 Feb 2017

[31] Ren DM (2016) Prospect of renewable energy development in $13^{\text {th }}$ Five-Year period. Sci Technol Rev 34(1):133-138

[32] Sohu Finance (2017) National energy administration: renewable energy will account for $27 \%$ of total electricity in 2020. http:// www.sohu.com/a/123488513_560697. Accessed 5 Jan 2017

[33] Xi Y (2014) Research on government subsidy support, technology innovation and performance of new energy industry. Dissertation, Nanjing University of Finance and Economics, Jiangsu

[34] Xu J, Chang SY, Yuan ZH et al (2015) Regionalized technoeconomic assessment and policy analysis for biomass molded fuel in China. Energies 8(12):13846-13863

[35] Zhang O, Yu SK, Liu PK (2015) Development mode for renewable energy power in China: electricity pool and distributed generation units. Renew Sustain Energy Rev 44:657-668

[36] Tan ZF, Chen KT, Liu PK (2015) Possibilities and challenges of China's forestry biomass resource utilization. Renew Sustain Energy Rev 41:368-378

[37] Zhang F (2016) Have the natural resource endowment promoted the manufacturing industry's competitiveness? An empirical evidence from spatial durbin model. Soc Sci Beijing 7:55-64

[38] Yuan JH, Na CN, Xu Y (2015) Wind turbine manufacturing in China: a review. Renew Sustain Energy Rev 51:1235-1244

[39] Quitzow R, Huenteler J, Asmussen H (2017) Development trajectories in China's wind and solar energy industries: how technology-related differences shape the dynamics of industry localization and catching up. J Clean Prod 1(158):122-133

[40] Dong Q, Futawatari T (2015) A review of the progress in China's renewable energy generation, and its links with energy conservation, environmental degradation and economic growth. Fresenius Environ Bull 24(1):405-411

[41] Yu BS, Sun NS, Jiao J (2017) Current situation and development trend of energy storage technology and industry. Oil Forum 1:57-61

[42] Polaris Website of Solar Photovoltaic Network (2017) Renewable energy, such as solar energy and wind energy, has become a new hot spot of investment. http://guangfu.bjx.com.cn/news/ 20170112/803287.shtml?id=4141. Accessed 12 Jan 2017

[43] Gao H, Yang Y, Rao LB et al (2016) Development of global renewable energy. Int Pet Econ 24(4):1-5

[44] Ren Y, Tang W, Xu Y (2015) The new urbanization and Chinese infrastructure constructions. Urbanization and 
insfrastructure construction comparative studies between China and Brazil, 1st edn. Shanghai People's Publishing House, Shanghai, pp 159-179

[45] Chen YB, Xiao SY (2016) Reasons and Countermeasures of wind and solar curtailment phenomenon in renewable energy sector. China Econ Trade Her 17:15-17

[46] Zhou CY, Yang HQ (2013) Study on industrial difference and energy saving potential of industrial energy efficiency in China. J Shanxi Univ Finance Econ 9:84-93

[47] Zhang M (2014) The driving force of enterprise independent innovation and measures for collaborative operation of its factors. Glob J Manag Bus Res. https://journalofbusiness.org/index. php/GJMBR/article/view/1487. Accessed 17 Aug 2018

[48] Polaris Website of Wind Power Network (2017) China's renewable energy development bottleneck will be great. http:// news.bjx.com.cn/html/20150605/627300.shtml. Accessed 5 June 2017

[49] Tang LH (2015) Strategic choice for national adjustment of renewable energy in China. In: Proceedings of the 3rd international conference on advances in energy and environmental science (ICAEES 2015). Zhuhai, China, 25-26 July 2015

[50] Gao XY (2016) Study on the development of renewable energy industry in China. J Hunan Finance Econ Univ 32(3):99-105

[51] Swaine MD (2015) Chinese views and commentary on the "one belt, one road" initiative. http://www.hoover.org/sites/default/ files/research/docs/clm47ms.pdf. Accessed 1 Apr 2015

[52] Qin HY (2015) Internationalization of wind power in "belt and road initiative". Wind Energy 3:1

[53] Xia YZ, Wang ZF, Feng LL (2014) Characteristics and development trend of PPP model for China clean energy funding. China State Finance 9:27-28

[54] Sun Y, Xu P, Shan BG et al (2016) Road map for "internet plus" energy substitution in electricity retail market reform in China. Power Syst Technol 40(12):3648-3654

[55] Xue HF, Wang HN (2010) Review of implementation of renewable energy law and outlook. Sino Glob Energy 12(11):3164

[56] Tan ZF, Liu WY, Liu PK (2014) Policy effect of tradable green certificate and carbon emission trading on china's electric power market. Technol Econ 33(9):74-84

[57] Zhao XG, Tan ZF, Liu PK (2013) Development goal of $30 \mathrm{GW}$ for China's biomass power generation: Will it be achieved? Renew Sustain Energy Rev 25:310-317

[58] WeH Xiao, Ye J (2016) Comparison and policy choice of the mechanism of renewable energy pricing. J Jiangxi Univ Finance Econ 1:21-27
[59] Mihaylov M, Razo-Zapata IS, Rădulescu R et al (2016) Boosting the renewable energy economy with NRGcoin. In: Conference: ICT for sustainability 2016. https://doi.org/10. 2991/ict4s-16.2016.27

[60] Leonhard RD (2016) Developing renewable energy credits as cryptocurrency on Ethereum's blockchain. Social Science Electronic Publishing, Rochester. https://doi.org/10.2139/ssrn. 2885335

[61] Zhang HP (2015) Research on the implementation capacity of the Chinese government's public policy from the perspective of social capital. Dissertation, Gansu Agricultural University, Lanzhou City

[62] Zhao XG, Liu XM, Liu PK et al (2011) The mechanism and policy on the electricity price of renewable energy in China. Renew Sustain Energy Rev 15(9):4302-4309

[63] Shi JL (2015) Development situation of China's renewable energy. Autom Panor 5:40-43

[64] Liu PK, Tan ZF (2016) How to develop distributed generation in China: in the context of the reformation of electric power system. Renew Sustain Energy Rev 66:10-26

[65] Li WQ (2016) Research on the construction of interest guarantee mechanism for social capital in PPP. Sci New Ground 7:70-72

[66] Zhang H (2016) Obstacles and countermeasures of private capital participating in PPP projects. South China Finance 10:79-83

[67] Zhou L (2017) The cooperation between government and social capital with respect to financing system. Roperty Rights Guide $3: 32-37$

Pingkuo LIU received the Bachelor's degree in Human Resource Management in 2010, the Master's degree in Management Science and Engineering in 2013, and the Ph.D. degree in Economics and Management of Technology in 2016, respectively, all from North China Electric Power University, Beijing, China. He is currently a Lecturer of the College of Economics and Management, Shanghai University of Electric Power, China. His research direction includes energy economics, electricity market optimization and industry economics.

Penghao CHU is the Postgraduate of the College of Economics and Management, Shanghai University of Electric Power, China. His research direction is power engineering economics and management. 